\title{
Efficient Photocatalytic Degradation of Salicylic Acid by Bactericidal ZnO
}

\author{
Chockalingam Karunakaran*, Binu Naufal, and Paramasivan Gomathisankar \\ Department of Chemistry, Annamalai University, Annamalainagar 608002, Tamilnadu, India \\ ${ }^{*}$ E-mail: karunakaranc@rediffmail.com
}

(Received October 5, 2011; Accepted December 18, 2011)

\begin{abstract}
Salicylic acid degrades at different rates under UV-A light on $\mathrm{TiO}_{2}, \mathrm{ZnO}, \mathrm{CuO}, \mathrm{Fe}_{2} \mathrm{O}_{3}, \mathrm{Fe}_{3} \mathrm{O}_{4}$ and $\mathrm{ZrO}_{2}$ nanocrystals and all the oxides exhibit sustainable photocatalysis. While ZnO-photocatalysis displays Langmuir-Hinshelwood kinetics the others follow first order on [salicylic acid]. The degradation on all the oxides enhance with illumination intensity. Dissolved oxygen is essential for the photodegradation. $\mathrm{ZnO}$ is the most efficient photocatalyst to degrade salicylic acid. Besides serving as the effective photocatalyst to degrade salicylic acid it also acts as a bactericide and inactivates E.coli even in absence of direct light.
\end{abstract}

Key words: Semiconductor, Nanoparticles, Photodegradation, Bactericidal activity

\section{INTRODUCTION}

Semiconductors under light of energy not less than the band gap produce electron-hole pairs, holes in the valence band $(\mathrm{VB})$ and electrons in the conduction band (CB). Some of the photogenerated charge carriers move to the crystal surface and react with the adsorbed molecules or ions and thus bring in photocatalysis. ${ }^{1}$ The hole reacts with adsorbed hydroxide ion or water molecule to generate short lived $\mathrm{HO}^{\circ}$ radical which is the primary oxidizing agent. The adsorbed $\mathrm{O}_{2}$ molecule picks up the $\mathrm{CB}$ electron transforming into highly active superoxide radical $\left(\mathrm{O}_{2}-{ }^{-}\right)$. In presence of moisture, $\mathrm{O}_{2}-$ in turn produces reactive species like $\mathrm{HO}, \mathrm{HO}_{2}$ and $\mathrm{H}_{2} \mathrm{O}_{2}$ which act as oxidizing agents. Because of the exceptional optical and electronic properties, chemical stability, non-toxicity and low cost, $\mathrm{TiO}_{2}$ is a promising material for photocatalytic applications. $\mathrm{ZnO}$ also displays such characteristics and its band gap is close to that of $\mathrm{TiO}_{2},{ }^{2}$ both the oxides require UV-A light for band gap excitation. Further, the $\mathrm{CB}$ and $\mathrm{VB}$ edges of $\mathrm{ZnO}$ do not differ significantly from those of $\mathrm{TiO}_{2}{ }^{2}$ The present work on photodegradation of salicylic acid shows the superior photocatalytic activity of $\mathrm{ZnO}$. Small band gap semiconductors like $\mathrm{CuO}, \mathrm{Fe}_{2} \mathrm{O}_{3}$, and $\mathrm{Fe}_{3} \mathrm{O}_{4}$ and large band gap semiconductor such as $\mathrm{ZrO}_{2}$ display poor photocatalytic activity. Salicylic acid is known for its ability to ease aches and pains and reduce fever. It is used as an anti-inflammatory drug. Although there are reports on photodegradation of salicylic acid they are with $\mathrm{TiO}_{2}$ as photocatalyst. Chhor et al., ${ }^{3}$ have compared the photodegradation of salicylic acid on $\mathrm{TiO}_{2}$ Degussa P25,
Sachtlaben Hombikat UV 100 and $\mathrm{Acros} \mathrm{TiO}_{2}$ with that on porous $\mathrm{TiO}_{2}$ and mixed mesoporous $\mathrm{SiO}_{2}: \mathrm{TiO}_{2}(95: 5 \mathrm{in}$ molar ratio). Combustion-synthesized $\mathrm{TiO}_{2}$ shows larger degradation than $\mathrm{TiO}_{2}$ Degussa $\mathrm{P} 25$ and it is attributed to crystallinity, surface area, surface hydroxyl groups, and optical absorption. ${ }^{4}$ The flame-made $\mathrm{TiO}_{2}$ powder is slightly better than $\mathrm{TiO}_{2}$ Degussa P25 and the degradation follows Langmuir-Hinshelwood kinetics. ${ }^{5}$ Photodegradation of salicylic acid on $\mathrm{TiO}_{2}$ aerosol, ${ }^{6} \mathrm{TiO}_{2}$ film, ${ }^{7} \mathrm{TiO}_{2}$ containing mesoporous SBA-15 silica, ${ }^{8} \mathrm{TiO}_{2}$-coated quartz ${ }^{9}$ or sand, ${ }^{10}$ Pt-loaded rutile $\mathrm{TiO}_{2}{ }^{11}$ and phthalocyanine-sensitized $\mathrm{TiO}_{2}{ }^{12}$ have been reported. $\mathrm{ZrO}_{2} / \mathrm{TiO}_{2}{ }^{13}$ also effects the photodegradation and $\mathrm{TiO}_{2}$ on $\mathrm{Al}_{2} \mathrm{O}_{3}$ shows better photocatalytic activity than pure $\mathrm{TiO}_{2}{ }^{14}$ Recently, $\mathrm{WO}_{3}$-loaded $\mathrm{TiO}_{2}{ }^{15}$ and modified $\mathrm{AlFe}_{2} \mathrm{O}_{3}{ }^{16}$ have been shown to photodegrade salicylic acid.

Bacterial contamination of surface water is prevalent in tropical countries and requires disinfection. Use of inorganic bactericides in place of organic molecules has attracted interest because of their improved safety and stability. ${ }^{17,18}$ Insoluble ceramics with inherent antibacterial activity are convenient to use. Our results reveal that $\mathrm{ZnO}$, besides the bactericidal activity acts as an effective photocatalyst to degrade salicylic acid. That is, it is a photocatalyst-cumbactericide providing a two-in-one advantage. In this work Escherichia coli (E. coli) is employed as an index to assess the bactericidal activity.

\section{EXPERIMENTAL}

\section{Materials}

$\mathrm{TiO}_{2}, \mathrm{ZnO}, \mathrm{CuO}, \mathrm{Fe}_{2} \mathrm{O}_{3}, \mathrm{Fe}_{3} \mathrm{O}_{4}$, and $\mathrm{ZrO}_{2}$ nanoparticles 
used where those supplied by Sigma-Aldrich. Salicylic acid (Merck) was recrystallized from water. Other chemical used were of analytical grade.

\section{Characterization techniques}

The X-ray diffractograms (XRD) of the nanocrystals were obtained using a Bruker D8 system employing $\mathrm{Cu}$ $\mathrm{K} \alpha$ radiation at $1.5406 \AA$ in a $2 \theta$ range of $10-70^{\circ}$ at a scan rate of $0.05^{\circ} \mathrm{s}^{-1}$ with a tube current of $30 \mathrm{~mA}$ at $40 \mathrm{kV}$. Rich. Siefert model $3000 \mathrm{X}$-ray diffractrometer was also used to record the XRD. The UV-visible diffuse reflectance spectra (DRS) of the oxides were recorded with a PerkinElmer Lambda 35 or Varian-Cary 5E or Shimadzu UV-2450 spectrophotometer.

\section{Estimation of salicylic acid}

Salicylic acid was estimated fluorimetrically or spectrophotometrically. The fluorescence spectra of salicylic acid of different concentrations were recorded using an Elico SL 174 spectrofluorimeter. The wavelength of excitation was $286 \mathrm{~nm}$ and $410 \mathrm{~nm}$ was the emission wavelength. A calibration curve was constructed to estimate salicylic acid in the test solution. Salicylic acid was also estimated spectrophotometrically by complexing with $\mathrm{Fe}^{3+}$ in mildly acidic solution; $9 \mathrm{~mL}$ of the solution was mixed with $1 \mathrm{~mL}$ of $0.01 \mathrm{M}$ ferric ammonium sulfate in $0.02 \mathrm{M} \mathrm{HCl}$. The complex shows an absorption maximum at $527.5 \mathrm{~nm}$ and conforms to the Beer-Lambert law.

\section{Photodegradation}

A photoreactor with eight 8-W mercury lamps of wavelength $365 \mathrm{~nm}$ (Sankyo Denki, Japan) and highly polished aluminum reflector was employed for the photocatalytic study. The reactor was cooled by fans fixed at the bottom. Borosilicate glass tube of $15-\mathrm{mm}$ inner diameter was used as the reaction vessel. Fresh solutions of salicylic acid were prepared and estimated fluorimetrically or spectrophotometrically. The volumes of solution used in multilamp photoreactor and microreactor were 20 and $10 \mathrm{~mL}$, respectively. Air was bubbled through the reaction solution using a micro air pump that effectively stirred the solution and kept the suspended catalyst under constant motion. The air-flow rate was measured by soap bubble method. The dissolved oxygen was estimated using an Elico dissolved oxygen analyzer PE 135 . The undegraded salicylic acid was estimated fluorimetrically or spectrophotometrically after separation of the catalyst. The exponential decrease of salicylic acid-concentration for a finite time of illumination ( 30 or 15 or $10 \mathrm{~min}$ ) provided the degradation rates and the results were reproducible to $\pm 5 \%$.

\section{Bacteria disinfection Nutrient broth culture}

Thirteen gram of nutrient broth $(5.0 \mathrm{~g}$ peptone, $5.0 \mathrm{~g}$ $\mathrm{NaCl}, 2.0 \mathrm{~g}$ yeast extract, $1.0 \mathrm{~g}$ beef extract) was dissolved in $1000 \mathrm{~mL}$ distilled water (pH 7.4) and sterilized in an autoclave at $121{ }^{\circ} \mathrm{C}$.

\section{MacConkey agar plate}

Fifty five gram of MacConkey agar (20 g peptic digest of animal tissue, $10 \mathrm{~g}$ lactose, $5 \mathrm{~g}$ sodium taurocholate, $0.04 \mathrm{~g}$ neutral red, $20 \mathrm{~g}$ agar) was dissolved in $1000 \mathrm{~mL}$ boiling distilled water, sterilized in an autoclave at $121^{\circ} \mathrm{C}$ and poured into Petri dish.

\section{Procedure}

E. coli was inoculated in $10 \mathrm{~mL}$ of a nutrient broth and incubated for $24 \mathrm{~h}$ at $37^{\circ} \mathrm{C}$. The culture was centrifuged at $3500 \mathrm{rpm}$, washed twice with autoclaved $0.9 \% \mathrm{NaCl}$ solution and suspended in $50 \mathrm{~mL}$ of $0.9 \% \mathrm{NaCl}$ solution. The E. coli solution was successively diluted $10^{9}$-times with $0.9 \% \mathrm{NaCl}$ solution to get about 100 to 200 colony forming units (CFU) on the Petri dish. $10 \mu \mathrm{L}$ of the diluted $E$. coli was streaked on the MacConkey agar plate using a loop and incubated at $37^{\circ} \mathrm{C}$ for $24 \mathrm{~h}$. The $\mathrm{CFU}$ was counted by a viable count method.

To $25 \mathrm{~mL}$ of $E$. coli solution in a $150 \mathrm{~mL}$ bottle $20 \mathrm{mg}$ of $\mathrm{ZnO}$ was added and shaken well continuously without any direct light. At different time intervals, one $\mathrm{mL}$ of the bacteria solution was removed, diluted stepwise and enumerated as stated already.

\section{RESULTS AND DISCUSSION}

\section{Catalysts characterization}

The XRDs of $\mathrm{TiO}_{2}$ samples displayed in Fig. 1 shows the anatase phase of the crystals. The recorded diffraction patterns match with the JCPDS pattern of $\mathrm{TiO}_{2}$ anatase (89-4921) revealing the body centered tetragonal crystal structure with $a$ and $b$ as $3.8101 \AA$ and $c$ as $9.3632 \AA$. The rutile lines (JCPDS 89-4202) are absent in the observed XRDs. The recorded diffractogram of $\mathrm{ZnO}$ confirms its zincite structure. The XRD agrees with the JCPDS pattern 89-7102 revealing primitive hexagonal crystal structure with $a$ and $b$ as $3.2526 \AA, c$ as 5.1888 $\AA$, $\alpha$ and $\beta$ as $90^{\circ}$ and $\gamma$ as $120^{\circ}$. The diffraction pattern of $\mathrm{CuO}$ matches with JCPDS 89-2529 pattern and shows the crystal structure as end centered monoclinic with crystal constants as: $a$

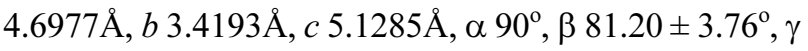




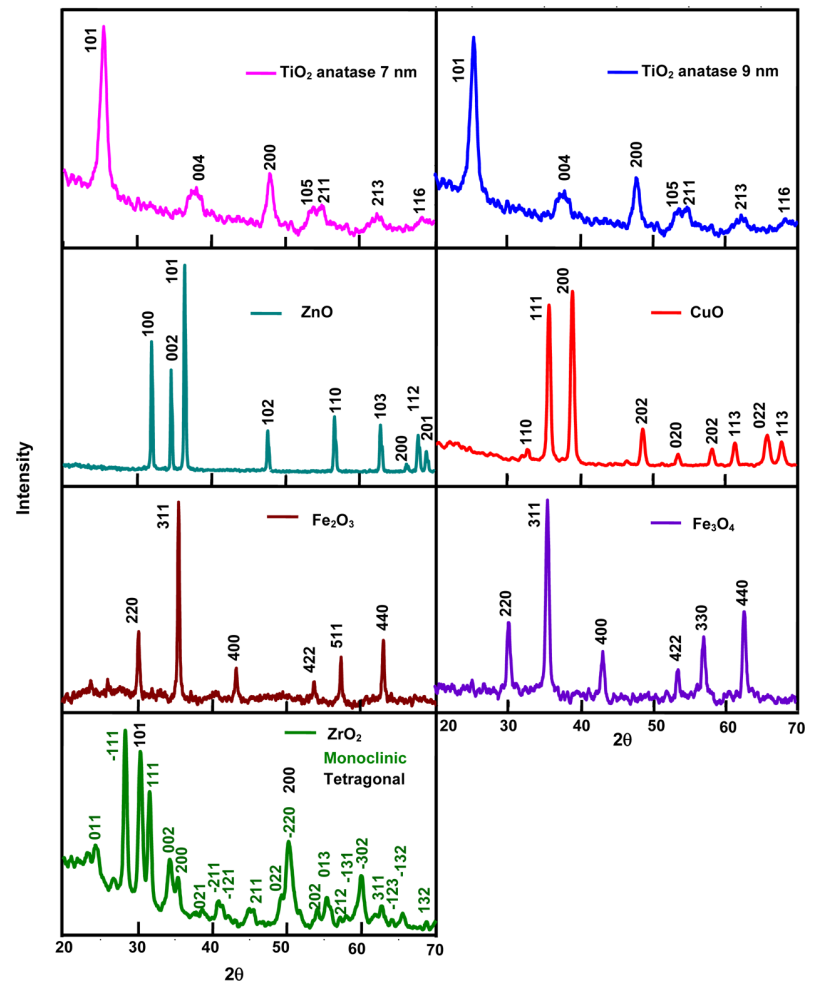

Fig. 1. The X-ray diffraction patterns.

$90^{\circ}$. The observed XRD pattern of $\mathrm{Fe}_{2} \mathrm{O}_{3}$ reveals the oxide as maghemite $\left(\gamma-\mathrm{Fe}_{2} \mathrm{O}_{3}\right)$. The pattern is in total agreement with JCPDS 39-1346 and the crystals belong to cubic system with unit cell length as $8.3515 \AA$. The $\mathrm{Fe}_{3} \mathrm{O}_{4}$ used is of face centered cubic system. The diffraction pattern is in agreement with JCPDS 89-4319 and the unit cell length is $8.3381 \AA$. The XRD peaks of zirconia show the oxide as a blend of monoclinic and tetragonal phases. The combined JCPDS patterns of monoclinic $\mathrm{ZrO}_{2}$ (24-1165) and tetragonal $\mathrm{ZrO}_{2}$ (81-1546) match with the recorded XRD. The crystal parameters are: primitive monoclinic (baddeleyite), $a 5.145 \AA, b 5.207 \AA, c 5.311 \AA, \alpha 90^{\circ}, \beta 99.23^{\circ}, \gamma$ $90^{\circ}$ and primitive tetragonal, $a$ and $b 3.622 \AA, c 5.205 \AA, \alpha$ $90^{\circ}, \beta 99.23^{\circ}, \gamma 90^{\circ}$. The volume fractions of the tetragonal $\left(\chi_{t}\right)$ and monoclinic $\left(\chi_{m}\right)$ phases are 0.34 and 0.66 , respectively. They have been obtained from the integrated peak intensities of the $(101)_{t}$ plane of the tetragonal phase $\left(I_{t}\right)$ and the $(111)_{m}$ and $(-111)_{m}$ planes of the monoclinic phase $\left(I_{m}\right)$ using the equations $\chi_{t}=I_{t(101)}\left[I_{t(101)}+I_{m(111)}+\right.$ $\left.I_{m(-111)}\right]$ and $\chi_{m}=1-\chi_{t}$. The average sizes of the nanoc- rystals $(D)$ have been obtained from the half-width of the full maxima (HWFM) of the most intense peaks of the oxides using the Scherrer formula $D=0.9 \lambda / \beta \cos \theta$, where $\lambda$ is the $X$-ray wavelength, $\theta$ is the Bragg angle and $\beta$ is the corrected line broadening. The specific surface areas of the nanoparticles have been deduced using the relationship $S=6 / d \rho$, where $S$ is the specific surface area, $d$ is the mean particle size and $\rho$ is the material density. Table 1 presents the results.

Fig. 2 displays the diffuse reflectance spectra (DRS) of the oxides. The reflectance data are presented as $F(R)$ value, obtained by the application of Kubelka-Munk (KM) algorithm $\left[F(R)=\left(1-R^{2}\right) / 2 R\right]$, where $R$ is the reflectance. The DRS clearly show insignificant absorption of UV-A light by $\mathrm{ZrO}_{2}$. Fig. 2 also displays the band gap excitation of $\mathrm{TiO}_{2}$ anatase and $\mathrm{ZnO}$ under UV-A radiation. The DRS of $\mathrm{Fe}_{2} \mathrm{O}_{3}$ and $\mathrm{CuO}$ exhibit the commencement of light absorption by the oxides at about 600 and $800 \mathrm{~nm}$, respectively. The DRS of $\mathrm{Fe}_{3} \mathrm{O}_{4}$ does not show any significant variation in the measured reflectance with visible and UV-A light. This is because of its reported band gap of about $0.1 \mathrm{eV} \cdot{ }^{19}$ The displayed K-M plots are in total agreement with the expected band gaps of the studied oxides. ${ }^{19}$ The band gap of $\mathrm{ZrO}_{2}$ is very wide (about 5 $\mathrm{eV}$ ) and hence does not show any significant absorption in the visible and UV-A region.

\section{Characteristics of photocatalytic degradation Langmuir-Hinshelwood kinetics on ZnO: Salicylic acid}

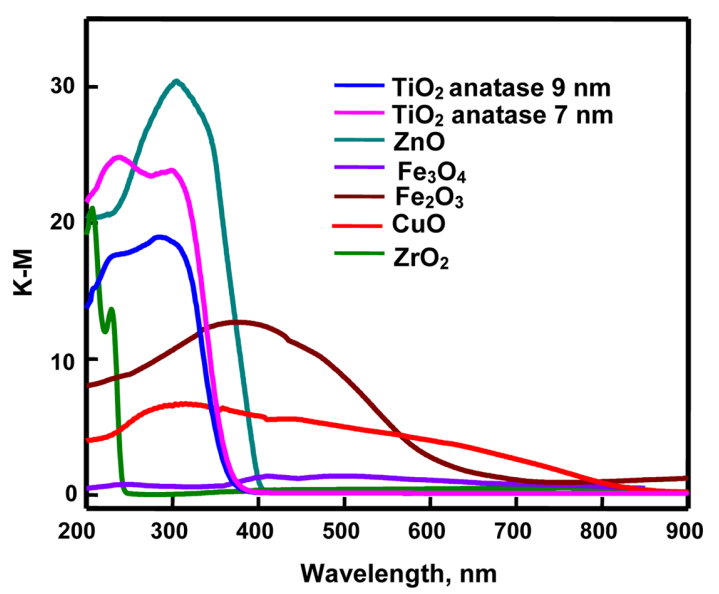

Fig. 2. The diffuse reflectance spectra.

Table 1. Crystal size and surface area

\begin{tabular}{cccccccc}
\hline & $\mathrm{ZnO}$ & $7-\mathrm{nm} \mathrm{TiO}_{2}$ & $9-\mathrm{nm} \mathrm{TiO}_{2}$ & $\mathrm{CuO}$ & $\mathrm{Fe}_{2} \mathrm{O}_{3}$ & $\mathrm{Fe}_{3} \mathrm{O}_{4}$ & $\mathrm{ZrO}_{2}$ \\
\hline Crystal size $(\mathrm{nm})$ & 32 & 7 & 9 & 28 & 39 & 32 & 25 \\
Surface area $\left(\mathrm{m}^{2} \mathrm{~g}^{-1}\right)$ & 33 & 210 & 165 & 33 & 32 & 36 & 42 \\
\hline
\end{tabular}


Table 2. Adsorption of salicylic acid on the nanocrystals

\begin{tabular}{cccccccc}
\hline Catalyst & $\mathrm{ZnO}$ & $7-\mathrm{nm} \mathrm{TiO}_{2}$ & $9-\mathrm{nm} \mathrm{TiO}_{2}$ & $\mathrm{CuO}$ & $\mathrm{Fe}_{2} \mathrm{O}_{3}$ & $\mathrm{Fe}_{3} \mathrm{O}_{4}$ & $\mathrm{ZrO}_{2}$ \\
\hline Adsorption $^{\mathrm{a}} \%$ & 0.98 & 2.7 & 2.5 & 1.2 & 0.73 & 3.4 & 2.6 \\
\hline
\end{tabular}

${ }^{\mathrm{a}} 0.02$ g-catalyst loading, $20 \mathrm{~mL} 0.41 \mathrm{mM}$ salicylic acid solution, $7.8 \mathrm{~mL} \mathrm{~s}^{-1}$ airflow rate, $18.2 \mathrm{mg} \mathrm{L}^{-1}$ dissolved $\mathrm{O}_{2}$.

degrades on $\mathrm{TiO}_{2}, \mathrm{ZnO}, \mathrm{CuO}, \mathrm{Fe}_{2} \mathrm{O}_{3}, \mathrm{Fe}_{3} \mathrm{O}_{4}$ and $\mathrm{ZrO}_{2}$ nanocrystals under UV-A light, albeit at different ease. Table 2 shows that adsorption of salicylic acid under the experimental conditions but in dark is negligible. The fluorescence and UV-visible spectral-time scans of salicylic acid solution illuminated by UV-A light with the listed nanocrystals show continuous removal of salicylic acid. Fig. 3 is a typical fluorescence spectral-time scan of the acid solution illuminated with $\mathrm{Fe}_{2} \mathrm{O}_{3}$. The corresponding UV-visible spectral time-scan of salicylic acid complexed with $\mathrm{Fe}^{3+}$ in mildly acidic solution is displayed in Fig. 4. The exponential decrease of salicylic acid-concentration with

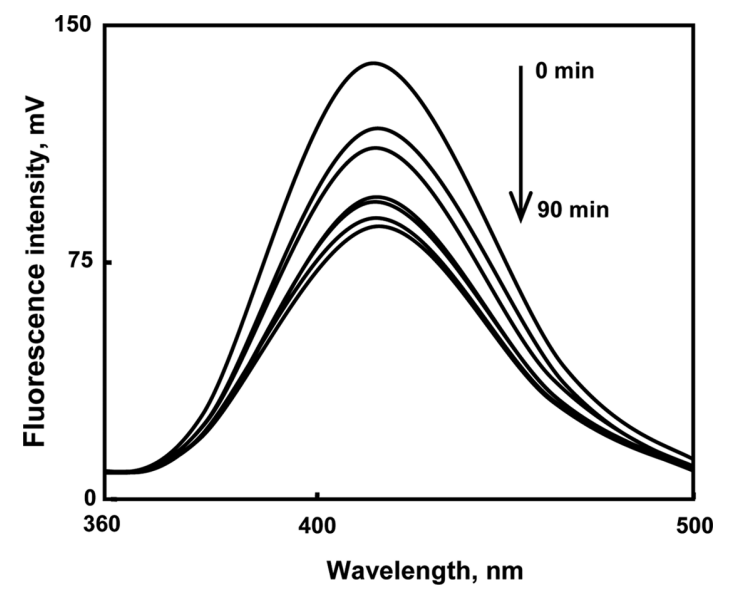

Fig. 3. Fluorescence spectral time-scan of salicylic acid illuminated with $\mathrm{Fe}_{2} \mathrm{O}_{3} .20 \mathrm{~mL}$ salicylic acid, $0.020 \mathrm{~g} \mathrm{Fe}_{2} \mathrm{O}_{3}$ loading, $7.8 \mathrm{~mL} \mathrm{~s}^{-1}$ airflow, $18.2 \mathrm{mg} \mathrm{L}^{-1}$ dissolved $\mathrm{O}_{2}, 365 \mathrm{~nm}, 19.2 \mu$ Einstein $\mathrm{L}^{-1} \mathrm{~s}^{-1}$.

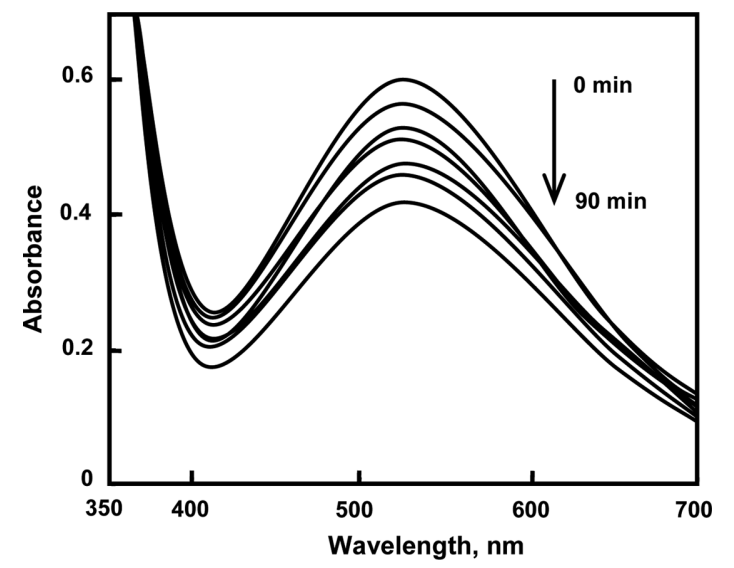

Fig. 4. UV-visible spectral time-scan of salicylic acid illuminated with $\mathrm{Fe}_{2} \mathrm{O}_{3}$ and complexed with $\mathrm{Fe}^{3+}$. Conditions as in Fig. 3.

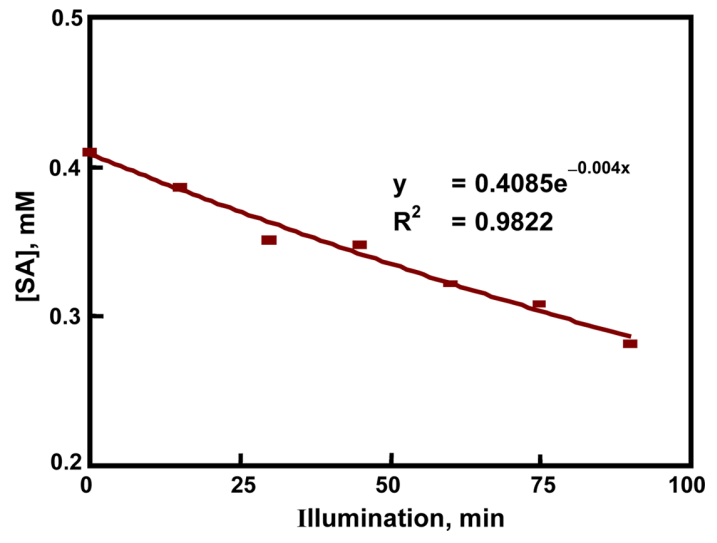

Fig. 5. Decay of salicylic acid with illumination time. Conditions as in Fig. 3.

illumination time reveals first-order photodegradation kinetics. Fig. 5 is a typical photodegradation time-profile. Fig. 6 displays the variation of degradation rates with salicylic acid-concentration photocatalyzed by the listed nanocrystals. While $\mathrm{ZnO}$-photocatalyzed salicylic acid degradation follows Langmuir-Hinshelwood kinetic model the rest show clean first order kinetics. The linear double reciprocal plot of rate versus salicylic acid-concentration displayed in Fig. 7 confirms the Langmuir-Hinshelwood model. The Langmuir-Hinshelwood kinetic equation is:

$$
\begin{aligned}
& \text { Degradation rate }=k K[\text { salicylic acid }] \\
& \quad /(1+K[\text { salicylic acid }])
\end{aligned}
$$

where $K$ is the adsorption coefficient of salicylic acid on the illuminated surface of the nanocrystals and $k$ is the surface pseudo-first-order rate constant. If the adsorption coefficient on the illuminated surface is too small so that 1 $>K$ [salicylic acid], the Langmuir-Hinshelwood kinetic equation reduces to the following simple first-order kinetic law:

Degradation rate $=k^{*}[$ salicylic acid $]$

where $k^{*}$ is the first-order rate constant and is equal to $k K$. That is, the degradation follows first-order kinetics under the experimental conditions studied. This accounts for the observed different photokinetic behaviors on the oxides. Here, it is pertinent to state that adsorption of substrate on illuminated surface is different from that on unilluminated surface, presented in Table 2. The observed Lang- 


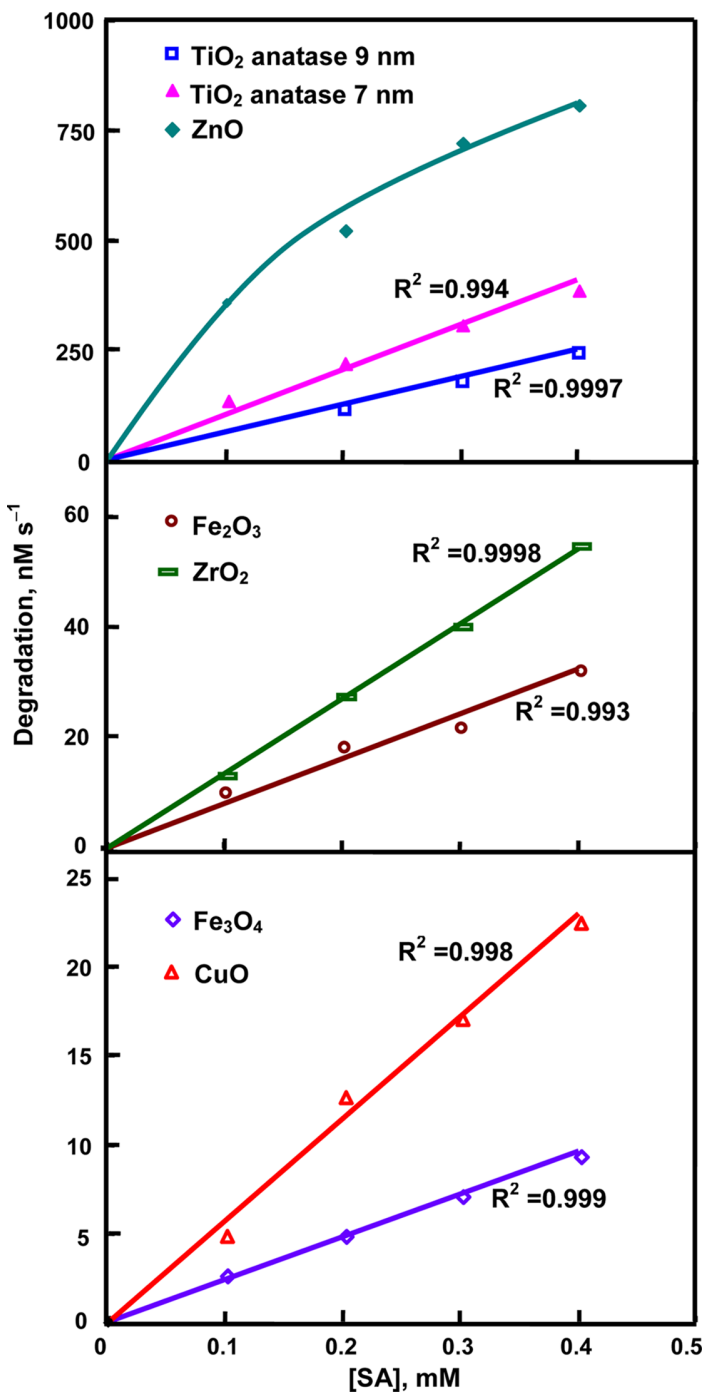

Fig. 6. Dependence of degradation rates on salicylic acid-concentration. $0.020 \mathrm{~g}$ oxide loading, $7.8 \mathrm{~mL} \mathrm{~s}^{-1}$ airflow, $18.2 \mathrm{mg} \mathrm{L}^{-1}$ dissolved $\mathrm{O}_{2}, 365 \mathrm{~nm}, 19.2 \mu$ Einstein $\mathrm{L}^{-1} \mathrm{~s}^{-1}, 20 \mathrm{~mL}$ salicylic acid solution.

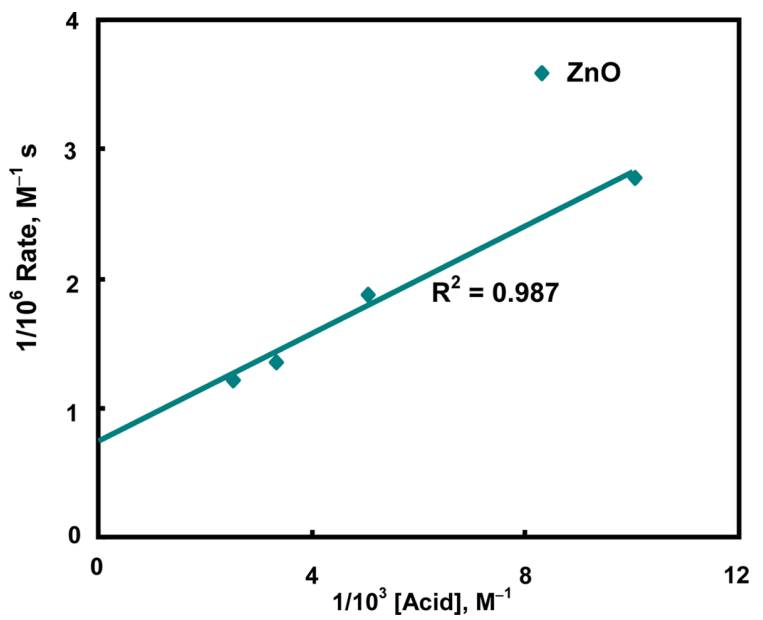

Fig. 7. ZnO-photocatalysis - Langmuir-Hinshelwood kinetic fit. Conditions as in Fig. 6.

muir-Hinshelwood kinetics of ZnO-photocatalysis and clean first-order kinetics on the surfaces of the rest of the oxides reveal that the photoadsorption is large on $\mathrm{ZnO}$ and negligible on the other oxides.

Other characteristics: The nanocrystals do not loose their photocatalytic activities on repeated usage. Reuse of the catalysts without any pre-treatment reveals sustainable photocatalysis by the oxides (Table 3). The photocatalysis requires dissolved oxygen. Deaeration of salicylic acid solution by purging nitrogen instead of air practically arrests the photodegradation in all the cases and Table 4 shows the measured degradation rates at different concentrations of dissolved oxygen. The dependence of salicylic acid-degradation on illumination-intensity is displayed in Fig. 8. The enhancement of degradation with photon flux is nonlinear. Generally, the photocatalysis is to enhance linearly with light intensity at low photon flux but at high

Table 3. Sustainable photocatalysis

\begin{tabular}{cccccccc}
\hline Catalyst & ${ }^{a} \mathrm{ZnO}$ & $7-\mathrm{nm}^{b} \mathrm{TiO}_{2}$ & $9-\mathrm{nm}^{b} \mathrm{TiO}_{2}$ & ${ }^{c} \mathrm{CuO}$ & ${ }^{c} \mathrm{Fe}_{2} \mathrm{O}_{3}$ & ${ }^{c} \mathrm{Fe}_{3} \mathrm{O}_{4}$ & ${ }^{c} \mathrm{ZrO}_{2}$ \\
\hline & 810 & 390 & Degradation, ${ }^{*} \mathrm{nM} \mathrm{s}^{-1}$ & & \\
Fresh & 810 & 390 & 250 & 23 & 32 & 9 & 55 \\
Reuse & 810 & 240 & 22 & 32 & 9 & 54
\end{tabular}

${ }^{*} 0.02$ g-catalyst loading, $20 \mathrm{~mL} 0.41 \mathrm{mM}$ salicylic acid solution, $7.8 \mathrm{~mL} \mathrm{~s}^{-1}$ airflow rate, $18.2 \mathrm{mg} \mathrm{L}^{-1}$ dissolved $\mathrm{O}_{2}, 365 \mathrm{~nm}, 19.2 \mu$ Einstein L ${ }^{-1} \mathrm{~s}^{-1}$, $10^{a}$ or $15^{b}$ or $30^{c}$ min-illumination.

Table 4. Photodegradation and dissolved $\mathrm{O}_{2}$

\begin{tabular}{|c|c|c|c|c|c|c|c|}
\hline & ${ }^{a} \mathrm{ZnO}$ & $7-\mathrm{nm}^{b} \mathrm{TiO}_{2}$ & 9-nm ${ }^{b} \mathrm{TiO}_{2}$ & ${ }^{c} \mathrm{CuO}$ & ${ }^{c} \mathrm{Fe}_{2} \mathrm{O}_{3}$ & ${ }^{c} \mathrm{Fe}_{3} \mathrm{O}_{4}$ & ${ }^{c} \mathrm{ZrO}_{2}$ \\
\hline$\left[\mathrm{O}_{2}\right]_{\text {dissolved }}, \mathrm{mg} \mathrm{L}^{-1}$ & \multicolumn{7}{|c|}{ Degradation, ${ }^{*} \mathrm{nM} \mathrm{s}^{-1}$} \\
\hline 19.2 & 810 & 390 & 250 & 23 & 32 & 9 & 55 \\
\hline 2.4 & 2 & 8 & 12 & 1 & 1 & 1 & 5 \\
\hline
\end{tabular}

${ }^{*} 0.02$ g-catalyst loading, $20 \mathrm{~mL} 0.41 \mathrm{mM}$ salicylic acid solution, $365 \mathrm{~nm}, 19.2 \mu$ Einstein $\mathrm{L}^{-1} \mathrm{~s}^{-1}, 10^{a}$ or $15^{b}$ or $30^{c}$ min-illumination. 


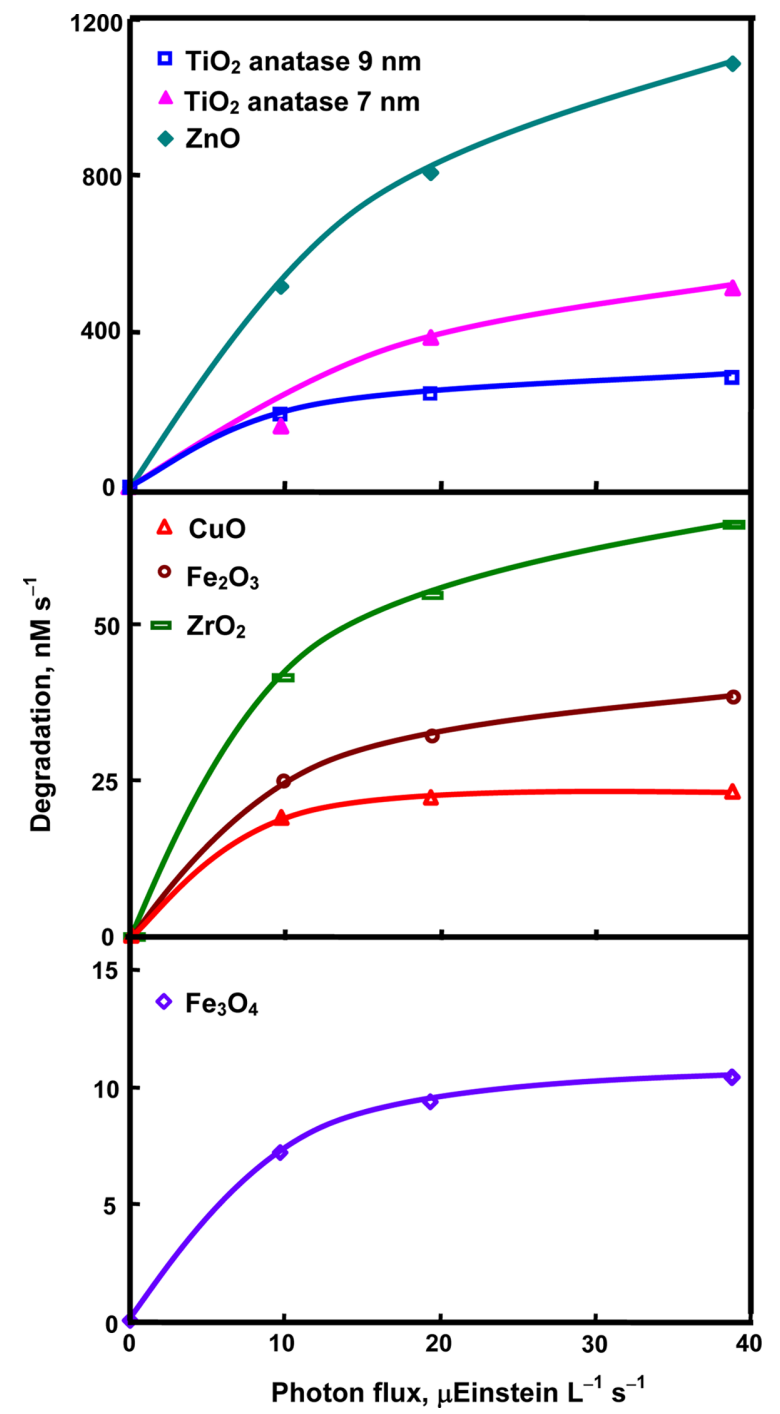

Fig. 8. Dependence of degradation rates on photon flux. $20 \mathrm{~mL}$ $0.41 \mathrm{mM}$ salicylic acid, $0.020 \mathrm{~g}$ oxide loading, $7.8 \mathrm{~mL} \mathrm{~s}^{-1}$ airflow, $18.2 \mathrm{mg} \mathrm{L}^{-1}$ dissolved $\mathrm{O}_{2}, 365 \mathrm{~nm}$.

light intensity its dependence is on the square-root of photon flux..$^{20,21}$ The present results conform to the same.

Figs. 6 and 8 show $\mathrm{ZnO}$ as the most efficient photocatalyst and $\mathrm{Fe}_{3} \mathrm{O}_{4}$ as the least efficient. The order of photocatalytic activity is: $\mathrm{ZnO}>7 \mathrm{~nm}-\mathrm{TiO}_{2}>9 \mathrm{~nm}-\mathrm{TiO}_{2}>\mathrm{ZrO}_{2}>$ $\mathrm{Fe}_{2} \mathrm{O}_{3}>\mathrm{CuO}>\mathrm{Fe}_{3} \mathrm{O}_{4}$. The least photocatalytic activity of $\mathrm{Fe}_{3} \mathrm{O}_{4}$ may be attributed to its band gap energy. The order of photocatalytic activity of $\mathrm{TiO}_{2}$ is in agreement with their average crystallite sizes. Smaller is the size lesser is the charge recombination. Further, decrease of crystallite size increases the surface area and the photocatalytic efficiency is proportional to the surface area. Although $\mathrm{ZrO}_{2}$ is a wide band gap semiconductor its photocatalytic activity under UV-A light is well known. ${ }^{22,23}$

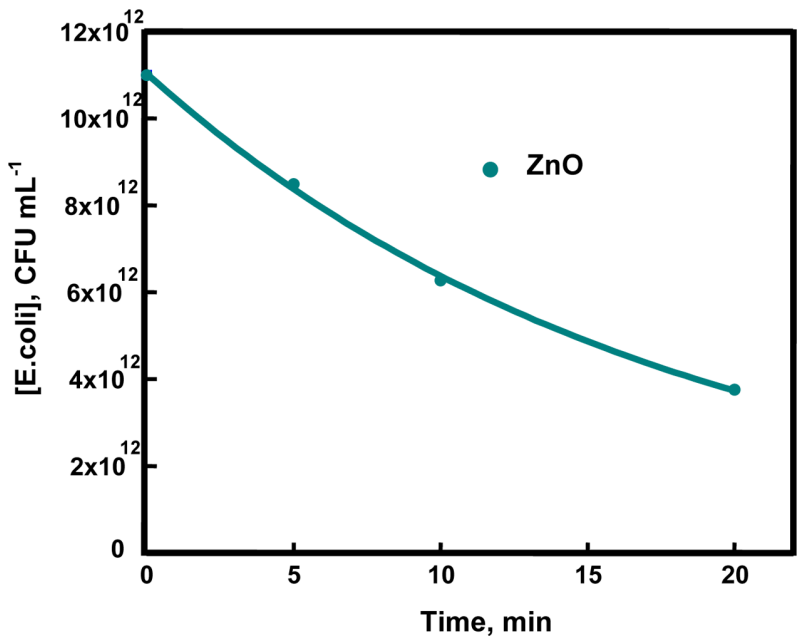

Fig. 9. Temporal profile of $E$. coli disinfection. $0.020 \mathrm{~g} \mathrm{ZnO}$ loading, $7.1 \mathrm{pH}, 25 \mathrm{~mL}$ E. coli solution.

\section{Bactericidal Activity}

Fig. 9 is the time profile of E. coli disinfection by $\mathrm{ZnO}$ in aqueous suspension in absence of direct light. In absence of the oxide the $E$. coli population remains unaffected during the experimental period displaying the bactericidal activity of the oxide. E. coli bacteria in $0.9 \%$ saline were used for the evaluation of the bactericidal activity. The cell population was determined by a viable count method on MacConkey agar plates after proper dilution of the culture. It is relevant to state that $\mathrm{TiO}_{2}$ does not inhibit bacteria in absence of direct light.

\section{CONCLUSIONS}

Wurtzite $\mathrm{ZnO}$ is the most efficient photocatalyst to degrade salicylic acid under UV-A light. $\mathrm{TiO}_{2}$ anatase, $\mathrm{CuO}, \gamma-\mathrm{Fe}_{2} \mathrm{O}_{3}$, $\mathrm{Fe}_{3} \mathrm{O}_{4}$ and $\mathrm{ZrO}_{2}$ (monoclinic:tetragonal::0.34:0.66) also photocatalyze the degradation of salicylic acid. The $\mathrm{ZnO}-$ photocatalysis follows Langmuir-Hinshelwood kinetics whereas the others display first-order kinetics on [salicylic acid]. The degradation enhances with the light intensity and essentially requires dissolved oxygen. $\mathrm{ZnO}$ also acts as a bactericide and inactivates $E$. coli even in absence of direct light.

\section{REFERENCES}

1. Hu, X.; Li, G.; Yu, J. C. Langmuir 2010, 26, 3031.

2. Hagfeldt, A.; Gratzel, M. Chem. Rev. 1995, 95, 49.

3. Chhor, K.; Bocquet, J. F.; Colbeau-Justin, C. Mater. Chem. Phys. 2004, 86, 123.

4. Nagaveni, K.; Sivalingam, G.; Hegde, M. S.; Madras, G. Environ. Sci. Technol. 2004, 38, 1600. 
5. Fotou, G. P.; Pratsinis, S. E. Chem. Eng. Commun. 1996, $151,251$.

6. Tomkiewicz, M. Catal. Today 2000, 58, 115.

7. Matthews, R. W. J. Phys. Chem. 1987, 91, 3328.

8. Wang, W.; Song, M. Micropor. Mesopor. Mater. 2006, 96, 255.

9. Hidaka, H.; Honjo, H.; Horikoshi, S.; Serpone, N. Catal. Commun. 2006, 7, 331.

10. Matthews, R. W. Wat. Res. 1991, 25, 1169.

11. Sun, B.; Smirniotis, P. G.; Boolchand, P. Langmuir 2005, 21,11398

12. Hodak, J.; Quinteros, C.; Litter, M. I.; Roman, E. S. J. Chem. Soc. Faraday Trans. 1996, 92, 5081.

13. Colon, G.; Hidalgo, M. C.; Navio, J. A. Appl. Catal., A 2002, 231, 185.

14. Anderson, C.; Bard, A. J. J. Phys. Chem. B 1997, 101, 2611.
15. Ismail, M.; Bousselmi, L.; Zahraa, O. J. Photochem. Photobiol. A 2011, 222, 314.

16. Shinde, S. S.; Bhosale, C. H.; Rajpure, K. Y. J. Mol. Catal. A 2011, 347, 65.

17. Jiang, W.; Mashayekhi, H.; Xing, B. Environ. Pollut. 2009, $157,1619$.

18. Hu, X.; Cook, S.; Wang, P.; Hwang, H.-M. Sci. Total Environ. 2009, 407, 3070.

19. Xu, Y.; Schoonen, M. A. A. Am. Mineral. 2000, 85, 543.

20. Karunakaran, C.; Senthilvelan, S.; Karuthapandian, S. J. Photochem. Photobiol. A 2005, 172, 207.

21. Vincze, L.; Kemp, T. J. J. Photochem. Photobiol. A 1995, 87, 257.

22. Karunakaran, C.; Sujatha, M. P.; Gomathisankar, P. Monatsh. Chem. 2009, 140, 1269.

23. Karunakaran, C.; Senthilvelan, S. J. Mol. Catal. A 2005, $233,1$. 